\title{
Total Synthesis and Evaluation of $\left[\Psi\left[\mathrm{CH}_{2} \mathrm{NH}\right] \mathrm{Tpg}{ }^{4}\right]$ Vancomycin Aglycon: Reengineering Vancomycin for Dual D-Ala-D-Ala and D- Ala-D-Lac Binding
}

\author{
Brendan M. Crowley and Dale L. Boger \\ Department of Chemistry and The Skaggs Institute for Chemical Biology, The Scripps Research \\ Institute, 10550 North Torrey Pines Road, La Jolla, CA 92037
}

\begin{abstract}
An effective synthesis of $\left[\Psi\left[\mathrm{CH}_{2} \mathrm{NH}\right] \mathrm{Tpg}^{4}\right]$ vancomycin aglycon (5) is detailed in which the residue 4 amide carbonyl of vancomycin aglycon has been replaced with a methylene. This removal of a single atom was conducted to enhance binding to D-Ala-D-Lac countering resistance endowed to bacteria that remodel their D-Ala-D-Ala peptidoglycan cell wall precursor by a similar single atom change (ester $\mathrm{O}$ for amide $\mathrm{NH}$ ). Key elements of the approach include a synthesis of the modified vancomycin $\mathrm{ABCD}$ ring system featuring a reductive amination coupling of residues 4 and 5 for installation of the deep-seated amide modification, the first of two diaryl ether closures for formation of the modified CD ring system (76\%, 2.5-3:1 kinetic atropodiastereoselectivity), a Suzuki coupling for installation of the hindered $\mathrm{AB}$ biaryl bond $(90 \%)$ on which the atropisomer stereochemistry could be thermally adjusted, and a macrolactamization closure of the $\mathrm{AB}$ ring system (70\%). Subsequent DE ring system introduction enlisted a room temperature aromatic nucleophilic substitution reaction for formation of the remaining diaryl ether (86\%, 6-7:1 kinetic atropodiastereoselectivity) completing the carbon skeleton of $\mathbf{5}$. Consistent with expectations and relative to the vancomycin aglycon, $\mathbf{5}$ exhibited a 40 -fold increase in affinity for D-Ala-D-Lac $\left(K_{\mathrm{a}}\right.$ $\left.=5.2 \times 10^{3} \mathrm{M}^{-1}\right)$ and a 35-fold reduction in affinity for D-Ala-D-Ala $\left(K_{\mathrm{a}}=4.8 \times 10^{3} \mathrm{M}^{-1}\right)$ providing a glycopeptide analogue with balanced, dual binding characteristics. Beautifully, 5 exhibited antimicrobial activity ( $\mathrm{MIC}=31 \mu \mathrm{g} / \mathrm{mL}$ ) against a VanA resistant organism that remodels its D-AlaD-Ala cell wall precursor to D-Ala-D-Lac upon glycopeptide antibiotic challenge displaying a potency that reflects these binding characteristics.
\end{abstract}

The most common strains of enterococci resistant to vancomycin (1), VanA and VanB, possess an inducible resistance pathway in which the terminal dipeptide of the cell wall peptidoglycan precursor is modified from D-Ala-D-Ala to D-Ala-D-Lac. ${ }^{1}$ Binding of the antibiotic to this modified ligand is reduced 1000-fold leading to a 1000-fold drop in antimicrobial activity. $1 \mathrm{~d}, \mathrm{k}$ In a recent disclosure, ${ }^{2}$ we provided the first experimental study on the origin of this loss in binding affinity, partitioning the effect into lost $\mathrm{H}$-bond and repulsive lone pair contributions, Figure 1 . Thus, the binding affinity of vancomycin for $\mathbf{3}$, which incorporates a methylene $\left(\mathrm{CH}_{2}\right)$ in place of the linking amide $\mathrm{NH}$ of $\mathrm{Ac}_{2}$-L-Lys-D-Ala-D-Ala, was compared with that of $\mathrm{Ac}_{2}$-L-Lys-D-Ala-D-Ala (2) and $\mathrm{Ac}_{2}$-L-Lys-D-Ala-D-Lac (4). The vancomycin affinity for $\mathbf{3}$ was approximately 10 -fold less than that of $\mathbf{2}$, but 100 -fold greater than that of $\mathbf{4}$. This indicated that the reduced binding affinity of $4(4.1 \mathrm{kcal} / \mathrm{mol})$ may be attributed to both the loss of a key H-bond and a destabilizing lone pair/lone pair interaction introduced with the ester oxygen of $4(2.6 \mathrm{kcal} / \mathrm{mol})$ with the latter, not the $\mathrm{H}$-bond, being responsible for the greater share (100-fold) of the 1000-fold binding reduction. These observations have significant

Email: boger@scripps.edu. 
ramifications on the reengineering of vancomycin to bind D-Ala-D-Lac suggesting that the design could focus principally on removing the destabilizing lone pair interaction rather than reintroduction of a $\mathrm{H}$-bond and that this may be sufficient to compensate for two of the three orders of magnitude in binding affinity lost with D-Ala-D-Lac. Thus, synthesis of a vancomycin analogue with removal of the residue 4 carbonyl and its destabilizing lone pair interaction could potentially restore much of the binding affinity of the antibiotic for the modified ligand. At present, such a deep-seated change in the molecule can only be achieved by total synthesis. ${ }^{3}$ Having developed a convergent and efficient synthesis of the vancomycin aglycon ${ }^{4}$ and having extended its effectiveness in the synthesis of the teicoplanin ${ }^{5}$ and ristocetin aglycons, ${ }^{6}$ we embarked on the total synthesis of $\left[\Psi\left[\mathrm{CH}_{2} \mathrm{NH}\right] \mathrm{Tpg}^{4}\right]$ vancomycin aglycon (5) in which the residue 4 carbonyl has been replaced with a methylene. Through such efforts, we were able to establish the effect this structural modification has on the binding affinity for both D-Ala-D-Ala and D-Ala-D-Lac and probe its impact on the antimicrobial activity of the analogue.

\section{Challenges and Synthetic Plan for $\left[\Psi\left[\mathrm{CH}_{2} \mathrm{NH}\right] \mathrm{Tpg}{ }^{4}\right]$ Vancomycin Aglycon}

The desired analogue 5 was anticipated to be prepared by a route analogous to that developed for vancomycin, ${ }^{4}$ with notable modifications. Thus, two aromatic nucleophilic substitution reactions with formation of the biaryl ethers would be enlisted for CD and DE macrocyclization, a key macrolactamization reaction would be employed for cyclization of the $\mathrm{AB}$ ring system, and the defined order of $\mathrm{CD}, \mathrm{AB}$, and $\mathrm{DE}$ ring closures was expected to permit sequential control of the atropisomer stereochemistry of each of the newly formed ring systems or their immediate precursors, Figure 2. Thus, in addition to any kinetic diastereoselection that may be achieved in the ring closures, this order was expected to permit the recycling of any undesired atropisomer for each newly introduced ring system by thermal equilibration providing a predictable control of the stereochemistry and dependably funneling all synthetic material into one of eight possible atropdiastereomers. Key to recognition of this preferential order of ring closures was our establishment of the thermodynamic parameters of atropisomerism for the individual vancomycin ring systems: DE ring system ${ }^{7}\left(E_{\mathrm{a}}=18.7 \mathrm{kcal} /\right.$ $\mathrm{mol})<\mathrm{AB}$ biaryl precursor ${ }^{4}\left(E_{\mathrm{a}}=25.1 \mathrm{kcal} / \mathrm{mol}\right)<\mathrm{CD}$ ring system ${ }^{7}\left(E_{\mathrm{a}}=30.4 \mathrm{kcal} / \mathrm{mol}\right)$. Thus, the molecule was to be assembled by coupling the modified and fully functionalized ABCD ring system $\mathbf{2 7}$ with the E ring tripeptide $\mathbf{2 8}$ followed by a diastereoselective aromatic nucleophilic substitution reaction for closure of the 16-membered DE ring system with formation of the biaryl ether linkage. Notably, the activating nitro substituent additionally serves as the precursor functionality for aryl chloride introduction and the analogous vancomycin ring closures $4,8-10$ were effected with preferential formation of the natural $(P)$ atropisomer. The E ring tripeptide $\mathbf{2 8}$ would be derived in the manner described for vancomycin ${ }^{4}$ except that the E ring subunit would be prepared enlisting an improved route developed during our more recent total synthesis of the ristocetin aglycon 6 employing an $\alpha-$ hydroxypinanone ${ }^{11}$ as the chiral auxiliary for a diastereoselective aldol addition. The most significant deviations rest with the required modifications in the preparation of the ABCD subunit which house the modified amide and include the use of a reductive amination coupling of residues 4 and 5 (D and B rings) with protection of the newly generated amine as a methyl carbamate and an experimentally-derived altered order to the assembly of the BCD tripeptide. A relatively small and robust amine protecting group was chosen to avoid the introduction of unfavorable steric interactions that may affect the CD macrocyclic ring closure and that would be stable throughout the synthesis, yet still be compatible with a final stage global deprotection. CD macrocyclization enlisting a key aromatic nucleophilic substitution reaction for formation of 16-membered biaryl ether followed by Suzuki coupling of the A ring subunit and AB macrolactamization was anticipated to complete the preparation of the modified ABCD ring system 27 enlisting a ring closure order that would permit the sequential and selective thermal adjustment of the $\mathrm{CD}$ and $\mathrm{AB}$ ring system atropisomer stereochemistry. Key unknown features 
of the approach include the feasibility of conducting the critical CD ring closure enlisting the residue 4 protected amine versus amide, the resulting unknown atropisomer stereochemical issues (kinetic and thermodynamic diastereoselectivity), and the impact the deep-seated structural change would have on the conformational features of the $\mathrm{CD}$ or $\mathrm{ABCD}$ ring systems and those of the final molecule. Finally, the subtle choices of a nitrile as a precursor to the residue 3 side chain carboxamide permits a final stage amide deprotection yet conveys stability to any projected thermal atropisomer equilibrations in its presence, ${ }^{7 f}$ and the use of a MEM protected hydroxymethyl precursor (vs a methyl ester) to the C-terminus carboxylic acid enhances the rate of the projected $\mathrm{AB}$ macrolactamization ${ }^{4}$ and precludes inadvertent epimerization throughout the synthesis.

\section{Synthesis of the BCD Tripeptide}

The B and D subunits $\mathbf{6}$ and 7 were prepared following previously optimized procedures. 6,7 Oxidation of alcohol $7^{12}$ (2.0 equiv of Dess-Martin periodinane, $\mathrm{CH}_{2} \mathrm{Cl}_{2}, 0-25^{\circ} \mathrm{C}, 1 \mathrm{~h}, 100 \%$ ) was followed by immediate reductive amination coupling of the sensitive aldehyde 8 with $6^{13}$ (1.1 equiv, $\mathrm{CH}_{3} \mathrm{OH}, 3 \AA \mathrm{MS}, 0^{\circ} \mathrm{C}, 45$ min; 3.0 equiv of $\mathrm{AcOH}, 3.0$ equiv of $\mathrm{NaBH}_{3} \mathrm{CN}$, $\left.-20^{\circ} \mathrm{C}, 2 \mathrm{~d}\right)$ to afford amine 9 in good yield (75\%) and excellent diastereoselectivity (12:1), Scheme 1 . Shorter reaction times $(14-20 \mathrm{~h})$ at higher temperatures $\left(-15\right.$ to $\left.-5^{\circ} \mathrm{C}\right)$ led to substandard selectivities (4:1 to 9:1) and the use of less $\mathrm{NaBH}_{3} \mathrm{CN}$ (1.5-2.0 equiv) or lower temperatures $\left(-30{ }^{\circ} \mathrm{C}\right)$ led to incomplete reactions. Longer reaction times $(3-8 \mathrm{~d})$ led to only marginal increases in yield ( $82 \%$ after $8 \mathrm{~d}$ ) and roughly equal diastereoselectivities. Initial efforts to prepare 9 directly by displacement of the mesylate derived from alcohol 7 were ineffective as were attempts to conduct the reductive amination with the $\mathrm{BC}$ dipeptide and $\mathbf{8}$. Amine protection of 9 as the methyl carbamate ( 10 equiv of $\mathrm{MeOCOCl}, 10$ equiv of $\mathrm{K}_{2} \mathrm{CO}_{3}$, THF, $0-25{ }^{\circ} \mathrm{C}, 18 \mathrm{~h}, 85 \%$ ) followed by benzyl ether deprotection ${ }^{14}$ (Raney Ni, $\mathrm{CH}_{3} \mathrm{OH}, 0^{\circ}$ $\mathrm{C}, 5 \mathrm{~h}, 98 \%$ ) and saponification (3.0 equiv of $\mathrm{LiOH}, \mathrm{THF}-\mathrm{H}_{2} \mathrm{O}, 0{ }^{\circ} \mathrm{C}, 6 \mathrm{~h}, 100 \%$ ) provided 12. Unexpectedly, the order of these latter two deprotections proved important. Saponification of $10^{15}$ under a variety of conditions $\left(\mathrm{LiOH}, \mathrm{THF}-\mathrm{H}_{2} \mathrm{O}\right.$ or $t-\mathrm{BuOH}-\mathrm{H}_{2} \mathrm{O},-10$ to $0^{\circ} \mathrm{C} ; \mathrm{LiOOH}$, THF- $\mathrm{H}_{2} \mathrm{O} ; \mathrm{Me}_{3} \mathrm{SnOH}, 1,2$-dichloroethane, $70^{\circ} \mathrm{C}$ ) led to variable amounts of an epimer (5$20 \%$ ) that was difficult to separate from the product. In contrast, benzyl ether deprotection of $\mathbf{1 0}$ followed by saponification of $\mathbf{1 1}$ reduced the amount of epimer (0-3\%) presumably due to preferential deprotonation of the phenols such that subsequent $C_{\alpha}$ deprotonation at residue 5 was less facile. ${ }^{15}$ Coupling of $\mathbf{1 2}$ with $\mathbf{1 3}^{16}$ (3.0 equiv of DEPBT, ${ }^{17} 3.0$ equiv of $\mathrm{NaHCO}_{3}$, DMF, $0-25{ }^{\circ} \mathrm{C}, 8 \mathrm{~h}$ ) gave tripeptide $\mathbf{1 4}$ in good yield (70\%) and excellent diastereoselectivity (14:1). A range of other more conventional coupling reagents (EDCI-HOAt, HATU, FDPP) also provided good conversions (65-80\%), but suffered from considerable competitive racemization.

\section{Synthesis of the ABCD Ring System}

This set the stage for a detailed examination of one of the critical reactions in the approach to $\mathbf{5}$ entailing the cyclization of $\mathbf{1 4}$. After considerable optimization (Supporting Information Tables S1 and S2), cyclization of $\mathbf{1 4}$ (20 equiv of $\mathrm{K}_{2} \mathrm{CO}_{3}, 20$ equiv of $\mathrm{CaCO}_{3}, 3$ wt equiv of $3 \AA \mathrm{MS}, 12 \mathrm{mM}$ THF, $75{ }^{\circ} \mathrm{C}$ bath temp, $12 \mathrm{~h}$ ) afforded $\mathbf{1 5}$ in good yield (54\%) and good atropodiastereoselectivity $(2.5: 1,15(54 \%)$ and $16(22 \%))$ even when conducted on a large scale $(2.7 \mathrm{~g})$, Scheme 2 . The inclusion of $\mathrm{CaCO}_{3}$ in the reaction mixture is critical and serves to trap the liberated fluoride arising from the aromatic nucleophilic substitution as an insoluble byproduct $\left(\mathrm{CaF}_{2}\right)$ preventing TBS ether deprotection and a subsequent competitive basecatalyzed retro aldol reaction of the free alcohol. Nearly comparable results were obtained by promoting the ring closure of $\mathbf{1 5}$ with the stronger base $t$-BuOK (1.0 equiv, THF, $-20^{\circ} \mathrm{C}, 18$ h) providing 15 and its atropisomer 16 in 57\% and 19\% (3:1 atropodiastereoselectivity), respectively, under remarkably mild reaction conditions $\left(-20^{\circ} \mathrm{C}\right.$, THF). However, the use of 
$t$-BuOK proved more sensitive to the reaction parameters, suffered competitive racemization if excess base was employed, and proved more difficult to implement on a large scale than the reaction enlisting $\mathrm{K}_{2} \mathrm{CO}_{3} / \mathrm{CaCO}_{3}$. The cyclization of 14 represents a considerable improvement over the analogous ring closure reaction enlisted in our original synthesis of vancomycin (50$65 \%, 1: 1$ atropisomers vs $76-87 \%, 2.5-3: 1$ atropisomers) where both the overall conversion and atropodiastereoselectivity were lower illustrating that the closure of $\mathbf{1 4}$ may benefit from the increased conformational flexibility of the cyclization substrate. ${ }^{18}$ Unlike the vancomycin $\mathrm{CD}$ ring system in which the atropisomers could be thermally equilibrated at $120-140{ }^{\circ} \mathrm{C}$ permitting the recycling and productive use of the unnatural atropisomer, the atropisomers 15 and 16 could not be thermally interconverted even at temperatures as high as $210-230^{\circ} \mathrm{C}$, Scheme 3.

Reduction of the nitro group (Raney $\mathrm{Ni}, 0{ }^{\circ} \mathrm{C}, \mathrm{CH}_{3} \mathrm{OH}, 1 \mathrm{~h}$ ) followed by diazotization (1.3 equiv of $\mathrm{HBF}_{4}, 1.3$ equiv of $t$ - $\mathrm{BuONO}, \mathrm{CH}_{3} \mathrm{CN}, 0^{\circ} \mathrm{C}, 30 \mathrm{~min}$ ) and Sandmeyer substitution (50 equiv of $\mathrm{CuCl}, 60$ equiv of $\mathrm{CuCl}_{2}, \mathrm{H}_{2} \mathrm{O}, 0-25^{\circ} \mathrm{C}, 1 \mathrm{~h}, 70 \%$ from 15 ) cleanly provided 17 without loss of the atropisomer stereochemistry inherent in starting $\mathbf{1 5}$. The unnatural atropisomer 16 was also subjected to these conditions to cleanly give $\mathbf{1 8}$ (75\%) (Scheme 3). The stereochemical assignments of these two compounds and their relationship as atropisomers (vs epimers) were established by $2 \mathrm{D}$ ROESY ${ }^{1} \mathrm{H}-{ }^{1} \mathrm{H}$ NMR experiments and confirmed chemically by their reductive dechlorination $\left(\mathrm{H}_{2}, 10 \%, \mathrm{Pd} / \mathrm{C}\right)$ to afford the identical product 19 (Scheme 3). Diagnostic NOE crosspeaks for 17 were observed between $\mathrm{C}_{5 \mathrm{a}}{ }^{6}-\mathrm{H} / \mathrm{C}_{3}{ }^{6}-\mathrm{H}(\mathrm{s})$, $\mathrm{C}_{5} \mathrm{a}^{6}-\mathrm{H} / \mathrm{C}_{2}{ }^{6}-\mathrm{H}(\mathrm{s}), \mathrm{C}_{5 \mathrm{~b}^{6}}{ }^{6} \mathrm{H} / \mathrm{C}_{6 \mathrm{~b}}{ }^{6}-\mathrm{H}(\mathrm{s}), \mathrm{C}_{5}{ }^{5}-\mathrm{H} / \mathrm{C}_{4 \mathrm{~b}^{5}}-\mathrm{H}(\mathrm{s}), \mathrm{C}_{3}{ }^{6}-\mathrm{H} / \mathrm{C}_{2}{ }^{6}-\mathrm{H}(\mathrm{s}), \mathrm{C}_{2}{ }^{5}-\mathrm{H} / \mathrm{C}_{4 \mathrm{a}^{5}}-\mathrm{H}(\mathrm{w})$,

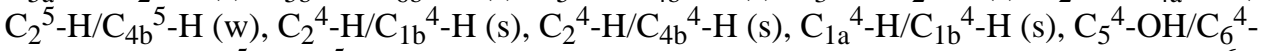
$\mathrm{OMe}(\mathrm{s})$, and $\mathrm{C}_{5}{ }^{5}-\mathrm{H}_{/} \mathrm{C}_{6}{ }^{5}-\mathrm{OMe}(\mathrm{m})$ and no NOE crosspeaks were observed between $\mathrm{C}_{5 \mathrm{~b}}{ }^{6}-\mathrm{H} /$ $\mathrm{C}_{3}{ }^{6}-\mathrm{H}$ and $\mathrm{C}_{5 \mathrm{~b}}{ }^{6}-\mathrm{H} / \mathrm{C}_{2}{ }^{6}-\mathrm{H}$. Diagnostic NOE crosspeaks for 18 were observed between $\mathrm{C}_{5 \mathrm{~b}}{ }^{6}-\mathrm{H} /$

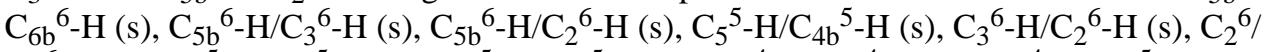

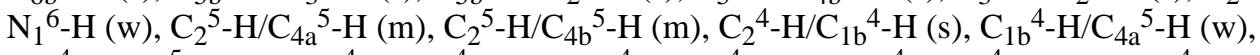
$\mathrm{C}_{1 \mathrm{~b}}{ }^{4}-\mathrm{H} / \mathrm{C}_{4 \mathrm{~b}}{ }^{5}-\mathrm{H}(\mathrm{w}), \mathrm{C}_{1 \mathrm{a}}{ }^{4}-\mathrm{H} / \mathrm{C}_{4 \mathrm{~b}}{ }^{4}-\mathrm{H}(\mathrm{s}), \mathrm{C}_{1 \mathrm{~b}}{ }^{4}-\mathrm{H} / \mathrm{C}_{1 \mathrm{a}}{ }^{4}-\mathrm{H}(\mathrm{s}), \mathrm{C}_{4 \mathrm{~b}}{ }^{4}-\mathrm{H} / \mathrm{C}_{5}{ }^{4}-\mathrm{OH}(\mathrm{m}), \mathrm{C}_{5}{ }^{4}-\mathrm{OH} /$ $\mathrm{C}_{6}{ }^{4}-\mathrm{OMe}(\mathrm{w}), \mathrm{C}_{5}{ }^{5}-\mathrm{H} / \mathrm{C}_{6}{ }^{5}-\mathrm{OMe}(\mathrm{w}), \mathrm{C}_{2}{ }^{4}-\mathrm{H} / \mathrm{N}_{1}{ }^{4}-\mathrm{H}(\mathrm{w})$ and no NOE crosspeaks were observed between $\mathrm{C}_{5} \mathrm{a}^{6}-\mathrm{H} / \mathrm{C}_{3}{ }^{6}-\mathrm{H}$ and $\mathrm{C}_{5 \mathrm{a}^{6}}-\mathrm{H} / \mathrm{C}_{2}{ }^{6}-\mathrm{H}$.

Suzuki coupling of $\mathbf{1 7}$ with the hindered A ring boronic acid $\mathbf{2 0} 4$ ( 0.3 equiv of $\mathrm{Pd}_{2}(\mathrm{dba})_{3}, 1.5$ equiv of (o-tol) $)_{3} \mathrm{P}$, toluene- $\mathrm{CH}_{3} \mathrm{OH}-1 \mathrm{~N}$ aq $\mathrm{Na}_{2} \mathrm{CO}_{3} 10: 3: 1,80^{\circ} \mathrm{C}, 30 \mathrm{~min}$ ) proceeded in excellent yield (90\%) under remarkably effective conditions ${ }^{4}$ given the steric constraints of the substrate 20 providing a separable 1:1.3 mixture of atropisomers (21:22) slightly favoring the unnatural configuration. Thermal equilibration of isolated $\mathbf{2 2}$ was carried out initially employing our reported conditions for vancomycin (o-dichlorobenzene, $120^{\circ} \mathrm{C}, 18 \mathrm{~h}, 81 \%$ recovery of material $)^{7}$ to afford a 1:1.1 separable mixture permitting the recycling of this unnatural atropisomer. An examination of the parameters for this isomerization $\left(k=0.12 \mathrm{~h}^{-1}\right.$, $t_{1 / 2}=5.9 \mathrm{~h}$ at $120^{\circ} \mathrm{C}$ and $k=0.36 \mathrm{~h}^{-1}, t_{1 / 2}=1.8 \mathrm{~h}$ at $135^{\circ} \mathrm{C}$ ) revealed that it proceeds with an energy of activation $\left(E_{\mathrm{a}}\right)$ of $25.6 \mathrm{kcal} / \mathrm{mol}\left(\Delta H^{*}=24.8 \mathrm{kcal} / \mathrm{mol}, \Delta S^{\ddagger}=-0.26\right.$ e.u., $\Delta G^{\ddagger}=24.9$ $\mathrm{kcal} / \mathrm{mol}$ ) essentially indistinguishable from that observed with the authentic vancomycin AB biaryl system, but it does not result in the analogues 3:1 thermodynamic preference for the natural atropisomer. However, the unusual and unexpected atropisomer stability of the CD ring system allowed us to improve on the recycling conditions. Heating the mixture in a microwave reactor at an elevated temperature $\left(210^{\circ} \mathrm{C}, o\right.$-dichlorobenzene) shortened the reaction time significantly ( $5 \mathrm{~min}$ vs $18 \mathrm{~h}$ ) and slightly improved the recovery of material (88\% vs $81 \%$ ). This improvement impacted the efficiency of the recycling of $\mathbf{2 2}$ by allowing multiple equilibrations to be run in a single day rather than over the course of a week. Silyl ether deprotection of 21 ( 1.2 equiv of $\mathrm{Bu}_{4} \mathrm{NF}$, THF, $0{ }^{\circ} \mathrm{C}, 10 \mathrm{~min}$ ) followed by $\mathrm{N}-\mathrm{Cbz}$ removal $\left(\mathrm{H}_{2}, 10 \% \mathrm{Pd} / \mathrm{C}, 1 \% \mathrm{Cl}_{3} \mathrm{CCO}_{2} \mathrm{H}-\mathrm{CH}_{3} \mathrm{OH}, 15 \mathrm{~min}, 95 \%\right)$ and methyl ester hydrolysis (1.0 equiv of $\mathrm{LiOH}, \mathrm{THF}-\mathrm{H}_{2} \mathrm{O}, 0{ }^{\circ} \mathrm{C}, 1 \mathrm{~h}, 96 \%$ ) gave amino acid 25 . Notably, N-Cbz removal in the absence of $\mathrm{Cl}_{3} \mathrm{CCO}_{2} \mathrm{H}^{5}$ was much slower $(11 \mathrm{~h})$ and these conditions led to competitive 
chloride reduction. ${ }^{19}$ Macrolactamization with closure of the $\mathrm{AB}$ ring system was effected by treatment of 25 with PyBOP (3.0 equiv, 6.0 equiv of $\mathrm{NaHCO}_{3}, 0.001 \mathrm{M} \mathrm{CH}_{2} \mathrm{Cl}_{2}-\mathrm{DMF} 5: 1$, $0-25^{\circ} \mathrm{C}, 12 \mathrm{~h}$ ) to afford the fully functionalized bicyclic ABCD ring system 26 in good yield $(70 \%)$ with only trace amounts of competitive epimerization $(<3 \%)$. Alternative coupling reagents (EDCI and HOAt or HOBt, HATU) and reaction conditions (10-100\% DMF$\mathrm{CH}_{2} \mathrm{Cl}_{2}, 3-5$ equiv of $\mathrm{Na}_{2} \mathrm{CO}_{3},-5$ to $0{ }^{\circ} \mathrm{C}$ ) led to lower conversions (30-52\%) or required extended reaction times ( $3 \mathrm{~d})$. N-Boc deprotection $\left(\mathrm{HCO}_{2} \mathrm{H}-\mathrm{CHCl}_{3} 1: 1,10 \mathrm{~h}, 84 \%\right)$ gave the free amine $\mathbf{2 7}$ for coupling with the $\mathrm{E}$ ring tripeptide. Confirmation of the atropisomer stereochemistry and amide conformational assignments for $\mathbf{2 6}$ were established by $2 \mathrm{D}$ ROESY ${ }^{1} \mathrm{H}-{ }^{1} \mathrm{H}$ NMR. Diagnostic NOE crosspeaks for $\mathbf{2 6}$ were observed between $\mathrm{C}_{5}{ }^{4}-\mathrm{OH} /$ $\mathrm{C}_{4 \mathrm{~b}}{ }^{4}-\mathrm{H}(\mathrm{s}), \mathrm{C}_{5}{ }^{4}-\mathrm{OH} / \mathrm{C}_{6}{ }^{4}-\mathrm{OMe}(\mathrm{s}), \mathrm{N}_{1}{ }^{7}-\mathrm{H} / \mathrm{C}_{4 \mathrm{a}}{ }^{5}-\mathrm{H}(\mathrm{s}), \mathrm{N}_{1}{ }^{7}-\mathrm{H} / \mathrm{C}_{2}{ }^{5}-\mathrm{H}(\mathrm{s}), \mathrm{N}_{1}{ }^{7}-\mathrm{H} / \mathrm{C}_{3}{ }^{6}-\mathrm{H}(\mathrm{m})$, $\mathrm{N}_{1}{ }^{7}-\mathrm{H} / \mathrm{C}_{2}{ }^{6}-\mathrm{H}(\mathrm{m}), \mathrm{C}_{5 \mathrm{a}}{ }^{6}-\mathrm{H} / \mathrm{C}_{3}{ }^{6}-\mathrm{H}(\mathrm{s}), \mathrm{C}_{5 \mathrm{a}}{ }^{6}-\mathrm{H} / \mathrm{C}_{2}{ }^{6}-\mathrm{H}(\mathrm{s}), \mathrm{C}_{5 \mathrm{~b}}{ }^{6}-\mathrm{H} / \mathrm{N}_{1}{ }^{6}-\mathrm{H}(\mathrm{m}), \mathrm{C}_{3}{ }^{6}-\mathrm{OH} / \mathrm{N}_{1}{ }^{6}-\mathrm{H}$

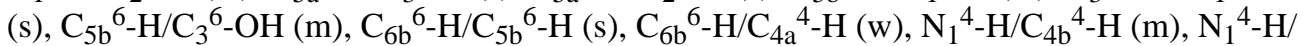

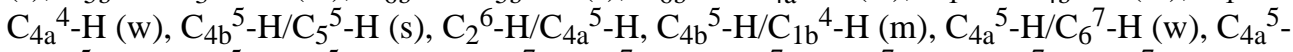
$\mathrm{H} / \mathrm{C}_{2}{ }^{5}-\mathrm{H}(\mathrm{s}), \mathrm{C}_{5}{ }^{5}-\mathrm{H} / \mathrm{C}_{6}{ }^{5}-\mathrm{OMe}(\mathrm{s}), \mathrm{C}_{4}{ }^{7}-\mathrm{H} / \mathrm{C}_{2}{ }^{7}-\mathrm{H}(\mathrm{s}), \mathrm{C}_{4}{ }^{7}-\mathrm{H} / \mathrm{C}_{1 \mathrm{~b}}{ }^{7}-\mathrm{H}(\mathrm{s}), \mathrm{C}_{4}{ }^{7}-\mathrm{H} / \mathrm{C}_{1 \mathrm{a}}{ }^{7}-\mathrm{H}(\mathrm{w})$, $\mathrm{C}_{4}{ }^{7}-\mathrm{H} / \mathrm{C}_{5} \mathrm{~b}^{7}-\mathrm{OMe}(\mathrm{s}), \mathrm{C}_{4}{ }^{7}-\mathrm{H} / \mathrm{C}_{6}{ }^{7}-\mathrm{H}(\mathrm{w}), \mathrm{C}_{6}{ }^{7}-\mathrm{H} / \mathrm{C}_{2}{ }^{5}-\mathrm{H}(\mathrm{w}), \mathrm{C}_{6}{ }^{7}-\mathrm{H} / \mathrm{C}_{5 \mathrm{~b}}{ }^{7}-\mathrm{OMe}(\mathrm{s}), \mathrm{C}_{6}{ }^{7}-\mathrm{H} /$

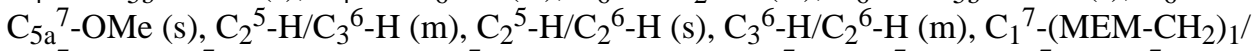
$\mathrm{C}_{1 \mathrm{a}}{ }^{7}-\mathrm{H}(\mathrm{s}), \mathrm{C}_{1}{ }^{7}-\left(\mathrm{MEM}-\mathrm{CH}_{2}\right)_{1} / \mathrm{C}_{1}{ }^{7}-\left(\mathrm{MEM}-\mathrm{CH}_{2}\right)_{2}(\mathrm{~s}), \mathrm{C}_{2}{ }^{7}-\mathrm{H} / \mathrm{C}_{1 \mathrm{~b}}{ }^{7}-\mathrm{H}(\mathrm{s}), \mathrm{C}_{2}{ }^{7}-\mathrm{H} / \mathrm{C}_{1 \mathrm{a}}{ }^{7}-\mathrm{H}(\mathrm{s})$ and no NOE crosspeaks were observed between $\mathrm{C}_{5 b^{6}}{ }^{6} \mathrm{H} / \mathrm{C}_{3}{ }^{6}-\mathrm{H}, \mathrm{C}_{5 \mathrm{~b}}{ }^{6} / \mathrm{C}_{2}{ }^{6}-\mathrm{H}, \mathrm{C}_{2}{ }^{6}-\mathrm{H} / \mathrm{C}_{3}{ }^{6}-\mathrm{OH}$, $\mathrm{N}_{1}{ }^{6}-\mathrm{H} / \mathrm{N}_{1}{ }^{7}-\mathrm{H}, \mathrm{N}_{1}{ }^{6}-\mathrm{H} / \mathrm{C}_{2}{ }^{5}-\mathrm{H}$, and $\mathrm{N}_{1}{ }^{6}-\mathrm{H} / \mathrm{C}_{4 \mathrm{a}}{ }^{5}-\mathrm{H}$. Most important in this spectroscopic assessment was not only the expected confirmation of the $\mathrm{CD}$ and $\mathrm{AB}$ atropisomer stereochemistry, but also the establishment of a vancomycin-like conformation for $\mathbf{2 6}$ bearing a cis amide linking the residues 5 and 6 (strong diagnostic $\mathrm{C}_{2}{ }^{5}-\mathrm{H} / \mathrm{C}_{2}{ }^{6}-\mathrm{H} N O E$ ) maintaining the spatial relationships and orientations of the $A B$ ring system (strong diagnostic $C_{2}{ }^{5}-H / C_{4 a}{ }^{5}-H$ and $\mathrm{C}_{2}{ }^{6}-\mathrm{H} / \mathrm{C}_{4 a}{ }^{5}-\mathrm{H}$ NOEs) and CD ring systems (diagnostic $\mathrm{C}_{6 \mathrm{~b}}{ }^{6}-\mathrm{H} / \mathrm{C}_{4 a}{ }^{4}-\mathrm{H}$ NOE). Although this might be considered unusual on the surface, even the natural atropisomer of the isolated $\mathrm{AB}$ ring system of vancomycin, without the surrounding $\mathrm{CD}$ ring system, adopts a conformation incorporating this cis amide structure illustrating that it is the confines of the $\mathrm{AB}$ ring system, not that of the $\mathrm{CD}$ ring system, that defines this key cis amide conformational preference. ${ }^{4}$ The lack of discernable NOEs to the methyl carbamate protecting the amine of the modified amide established that it extends out and away from the ABCD ring system binding pocket.

\section{Synthesis of the Full Carbon Skeleton}

Coupling of $\mathbf{2 7}$ and $\mathbf{2 8}$ (2.0 equiv of DEPBT, ${ }^{17} 2.2$ equiv of $\mathrm{NaHCO}_{3}, \mathrm{THF}, 0-25^{\circ} \mathrm{C}, 14 \mathrm{~h}$, $73 \%$ ) afforded 29 with excellent diastereoselectivity (12:1) arising from little competitive racemization, Scheme 4 . These conditions were utilized based on our experience with the teicoplanin ${ }^{5}$ and ristocetin 6 aglycons and are superior to those originally reported for vancomycin $^{4}$ (EDCI) in terms of diastereoselectivity (12:1 vs 3:1). Closure of the DE ring system with formation of the key biaryl ether was accomplished by treatment of $\mathbf{2 9}$ with CsF (10 equiv, 20 equiv of $\mathrm{CaCO}_{3}, 203 \AA \mathrm{MS}, \mathrm{DMF}, 25^{\circ} \mathrm{C}, 17 \mathrm{~h}$ ) to afford 30 in good yield (74\%) and good atropodiastereoselectivity (6-7:1). Notably, the closure of $\mathbf{3 0}$ was conducted under milder conditions than those originally disclosed for vancomycin ${ }^{4,7-10}$ (DMF vs DMSO at $25{ }^{\circ} \mathrm{C}$ with added $3 \AA \mathrm{MS}$ and $\mathrm{CaCO}_{3}$ ) and approaches the kinetic atropisomer diastereoselectivity observed in our efforts ${ }^{4}(8: 1)$, while surpassing that detailed in the related Evans ${ }^{10}$ efforts (5:1), and contrasts the closure detailed by Nicolaou ${ }^{21}$ (1:3) where the unnatural atropisomer predominated with an alternative substrate and method of ring closure. Thus, consistent with the adoption of a vancomycin-like conformation by $\mathbf{2 6}$, the amide modification in the ABCD ring system of $\mathbf{2 9}$ had little impact on the ease or diastereoselectivity of the DE ring closure. Reduction of the nitro group ${ }^{22}\left(\mathrm{H}_{2}, 10 \% \mathrm{Pd} / \mathrm{C}\right.$, THF, $\left.8 \mathrm{~h}, 94 \%\right)$ followed by diazotization of the resulting amine 32 (1.2 equiv of $\mathrm{HBF}_{4}, 1.2$ equiv of $t$-BuONO, 
$\mathrm{CH}_{3} \mathrm{CN}, 0{ }^{\circ} \mathrm{C}, 20 \mathrm{~min}$ ) and Sandmeyer substitution (50 equiv of $\mathrm{CuCl}, 60$ equiv of $\mathrm{CuCl}_{2}$,

$\mathrm{H}_{2} \mathrm{O}, 0-25^{\circ} \mathrm{C}, 1 \mathrm{~h}, 55 \%$ ) gave 33 , which embodies the full carbon skeleton of $\mathbf{5}$.

\section{Completion of the Synthesis}

With the full carbon skeleton in hand, attention was directed towards completion of the synthesis, Scheme 4 . TBS ether protection of the secondary alcohols (65 equiv of $\mathrm{CF}_{3} \mathrm{CONMeTBS}, \mathrm{CH}_{3} \mathrm{CN}, 55^{\circ} \mathrm{C}, 22 \mathrm{~h}$; aq citric acid, $25^{\circ} \mathrm{C}, 13 \mathrm{~h}, 96 \%$ ) followed by MEM ether deprotection of 34 (12 equiv of $B$-bromocatecholborane (BCB), $\mathrm{CH}_{2} \mathrm{Cl}_{2}, 0{ }^{\circ} \mathrm{C}, 2 \mathrm{~h} ; 5.1$ equiv of $\mathrm{Boc}_{2} \mathrm{O}, 6.0$ equiv of $\mathrm{NaHCO}_{3}$, dioxane- $\left.\mathrm{H}_{2} \mathrm{O} 2: 1,0-25{ }^{\circ} \mathrm{C}, 2.5 \mathrm{~h}, 80 \%\right)$ and two-step oxidation of the resulting primary alcohol 35 (4.0 equiv of Dess-Martin periodinane, $\mathrm{CH}_{2} \mathrm{Cl}_{2}, 0{ }^{\circ} \mathrm{C}, 15 \mathrm{~min}$ then $25^{\circ} \mathrm{C}, 1 \mathrm{~h} ; 9.0$ equiv of $80 \%$ aq $\mathrm{NaClO}_{2}, 7.0$ equiv of $\mathrm{NaH}_{2} \mathrm{PO}_{4} \cdot \mathrm{H}_{2} \mathrm{O}, t-\mathrm{BuOH} / 2$-methyl-2-butene $4: 1,25{ }^{\circ} \mathrm{C}, 20 \mathrm{~min}, 82 \%$ ) provided the carboxylic acid 36. Hydrolysis of the residue 3 nitrile with formation of the carboxamide 37 (40 equiv of $30 \%$ aq $\mathrm{H}_{2} \mathrm{O}_{2}, 8.0$ equiv of $10 \%$ aq $\mathrm{K}_{2} \mathrm{CO}_{3}$, DMSO, $\left.25^{\circ} \mathrm{C}, 3.5 \mathrm{~h}, 87 \%\right)^{4}$ set the stage for a final global deprotection. ${ }^{23}$ In a final key reaction, 37 was treated with $\mathrm{AlBr}_{3}$ (35 equiv, EtSH, $25^{\circ} \mathrm{C}, 5 \mathrm{~h}, 80 \%$ ) to afford 5 arising from the remarkable deprotection of four aryl methyl ethers, the two TBS ethers, the N-terminus Boc group, and the critical residue 4 methyl carbamate.

\section{Assessment of $\left[\Psi\left[\mathrm{CH}_{2} \mathrm{NH}\right] \mathrm{Tpg}{ }^{4}\right]$ Vancomycin Aglycon}

A subtle element in the design of 5 and choice of simply removing the residue 4 carbonyl rests with the projected properties of the molecule. In principle, one might consider reengineering the capabilities of a reverse H-bond into the vancomycin structure removing the destabilizing lone pair interaction with D-Ala-D-Lac and reinstating the lost H-bond. Such opportunities include amidine derivatives (e.g. $\left[\Psi[\mathrm{C}(=\mathrm{NH}) \mathrm{NH}] \mathrm{Tpg}^{4}\right]$ vancomycin aglycon 39, Figure 3$)$ and ongoing efforts have provided a thioamide intermediate we intend to use to access such derivatives. ${ }^{18}$ Significantly, such derivatives should enhance D-Ala-D-Lac binding approaching the level of affinity observed with vancomycin and D-Ala-D-Ala. However, these derivatives would also accordingly reduce binding to D-Ala-D-Ala. Consequently, they would be expected to gain antimicrobial activity against constituitively resistant bacteria endowed with a D-Ala-D-Lac peptidoglycan cell wall precursor (e.g. VanD), but be inactive against sensitive and inducibly resistant bacteria (VanA and $\operatorname{VanB}$ ) that maintain or at least start with a D-Ala-D-Ala peptidoglycan cell wall precursor. The closest modified vancomycins that would be expected to reproduce the binding results observed in Figure 1 are those that replace the amide bond linking residues 4 and 5 with a methylene $\left(\mathrm{CH}_{2} \mathrm{CH}_{2}\right)$ or ethylene $(\mathrm{CH}=\mathrm{CH})$ linker. Such derivatives, by analogy with the results in Figure 1, would be expected to enhance D-Ala-D-Lac affinity 100 -fold missing only the contribution to binding derived from the $\mathrm{H}$ bond. However, they might be expected to pay an additional penalty for binding D-Ala-D-Ala derived from not only the loss of the $\mathrm{H}$-bond (10-fold), but also for not satisfying a ligand $\mathrm{H}$ bond donor (10-fold?, for a cumulation 100-fold reduction?). As such, the derivatives might be expected to be marginally active against sensitive and inducibly resistant bacteria growing with a D-Ala-D-Ala peptidoglycan cell wall precursor (10 to 100-fold loss in activity), and more active against constituitively resistant bacteria (10-fold loss in activity) bearing the endowed D-Ala-D-Lac precursor. Consequently, and while we intend to examine such vancomycin analogues, they were not the first to be targeted for synthesis.

The targeted analogue 5 incorporating an amine in the linkage of residue 4 with residue 5 not only removes the offending carbonyl and the destabilizing lone pair interaction with D-AlaD-Lac, but it maintains a local polar environment (protonated amine) that may better accommodate the binding of an electronegative group or atom (NH of D-Ala-D-Ala amide or $\mathrm{O}$ of D-Ala-D-Lac ester). Intuitively, we anticipated that while this might not bind D-Ala-DLac quite as well as derivatives such as $\mathbf{4 0}$, it would be better than $\mathbf{4 0}$ at binding D-Ala-D-Ala. 
In the best case, $\mathbf{5}$ might bind D-Ala-D-Ala and D-Ala-D-Lac with equal affinities making it effective for the treatment of sensitive or resistant bacteria regardless of the structure of the peptidoglycan cell wall precursor. Notably, this dual binding results from a reduction in the affinity for D-Ala-D-Ala and an enhancement in the affinity for D-Ala-D-Lac such that the affinity for either splits that observed with vancomycin. Accordingly, while the spectrum of antimicrobial activity increases relative to vancomycin to include sensitive and resistant bacteria, the potency of the derivative would be anticipated to be reduced $30-40$ fold.

The results of our assessment of $\mathbf{5}$ alongside vancomycin (1) and its aglycon $\mathbf{3 8}$ are compiled in Table 1. An additional analogue 41, derived from N-Boc deprotection of the synthetic intermediate 33 (eq. 1), was also examined that bears the methoxycarbonyl protecting group on the residue 4/5 linking amine. The binding affinity of 5 for Ac 2 -L-Lys-D-Ala-D-Ala (2) and $\mathrm{Ac}_{2}$-L-Lys-D-Ala-D-Lac (4) was essentially equivalent (4.8 vs $5.2 \times 10^{3} \mathrm{M}^{-1}$, respectively) with the D-Ala-D-Lac binding being slightly better. Impressively, this represented the anticipated results relative to the vancomycin aglycon where the enhancement for binding D-Ala-D-Lac is 43 -fold $\left(5.2 \times 10^{3}\right.$ vs $\left.1.2 \times 10^{2} \mathrm{M}^{-1}\right)$ and the reduction in binding affinity for D-Ala-D-Ala is 37 -fold $\left(4.8 \times 10^{3}\right.$ vs $\left.1.7 \times 10^{5} \mathrm{M}^{-1}\right)$. In addition, the comparison of 5 with 41 seems to reflect the intuitive expectations of the impact of the polar amine (protonated) versus its carbamate derivative where the binding affinity for D-Ala-D-Ala with 5 versus 41 increases 3 -fold $\left(4.8\right.$ vs $\left.1.6 \times 10^{3} \mathrm{M}^{-1}\right)$ while the impact on D-Ala-D-Lac is a more marginal 1.2-fold increase in affinity $\left(5.2 \mathrm{vs} 4.1 \times 10^{3} \mathrm{M}^{-1}\right)$. Although there are additional structural features in the comparison of $\mathbf{5}$ and $\mathbf{4 1}$ that might impact the absolute affinities measured, in both instances the binding increases with the free amine $\mathbf{5}$ and it is with $\mathbf{5}$ that the dual binding is balanced.

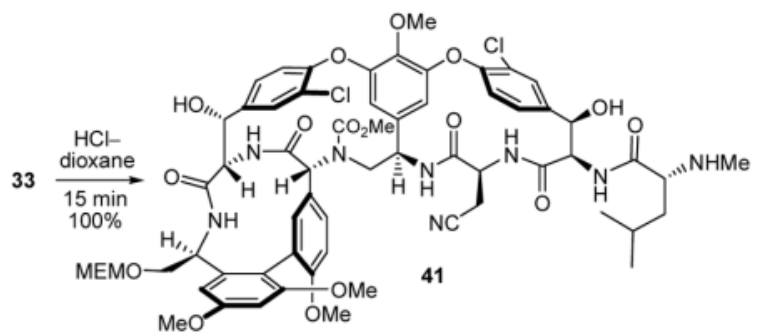

The four compounds were compared in an antimicrobial assay against VanA Enterococcus faecalis (BM4166) that is inducibly resistant to treatment by glycopeptide antibiotics including vancomycin and teicoplanin, Table 1 . It is the most difficult of the resistant organisms to treat (vs VanB) and characteristic of such organisms, they grow unchallenged enlisting a D-Ala-DAla peptidoglycan cell wall precursor, but switch to D-Ala-D-Lac upon glycopeptide treatment. As such, it represents a superb test of whether $\mathbf{5}$ and related dual D-Ala-D-Ala/D-Lac binding antibiotics might prove useful in the treatment of resistant bacteria. Beautifully, $\mathbf{5}$ as well as 41 exhibited MICs of $31 \mu \mathrm{g} / \mathrm{mL}$ being roughly 40 -fold more potent than vancomycin or its aglycon (MICs $=2000$ and $640 \mu \mathrm{g} / \mathrm{mL}$ ) correlating well with the ca. 40 -fold increase in binding affinity for D-Ala-D-Lac. Moreover, this potency is roughly 30 -fold weaker than that observed with vancomycin and its aglycon against sensitive E. faecalis (MICs $=1-2.5 \mu \mathrm{g} / \mathrm{mL}$ ) correlating with the 35 to 40 -fold loss in binding affinity for D-Ala-D-Ala. These results suggest that regardless of the peptidoglycan cell wall precursor utilized by the organism, it remains equally sensitive to treatment by $\mathbf{5}$ and $\mathbf{4 1}$. 


\section{Conclusions}

The modification of the dipeptide terminus of peptidoglycan cell wall precursors from D-AlaD-Ala to D-Ala-D-Lac in resistant bacteria reduces the binding affinity of vancomycin for the ligand by 1000 -fold leading to a 1000 -fold loss in biological activity. We had shown that a modified peptide ligand possessing a methylene in place of the lactate oxygen restores 100fold of this binding affinity by removal of a destabilizing lone pair interaction. This suggested that removal of the residue 4 carbonyl in the vancomycin aglycon would produce an analogue with enhanced affinity for D-Ala-D-Lac and might restore much of the biological activity of the molecule that is lost with resistant bacteria. Moreover and among the range of potential modifications that could be envisioned, that entailing the simple removal of the residue 4 carbonyl providing 5 was anticipated to bind D-Ala-D-Ala and D-Ala-D-Lac with similar affinities providing an analogue that might be equivalently effective against sensitive (D-AlaD-Ala) and resistant (D-Ala-D-Lac) bacteria. Consequently, we extended our efforts on the preparation of glycopeptide antibiotics to a total synthesis of the $\left[\Psi\left[\mathrm{CH}_{2} \mathrm{NH}\right] \mathrm{Tpg}^{4}\right]$ vancomycin aglycon (5) in which the residue 4 carbonyl has been replaced with a methylene. Consistent with expectations and relative to the vancomycin aglycon, $\mathbf{5}$ exhibited a 40 -fold increase in affinity for D-Ala-D-Lac $\left(K_{\mathrm{a}}=5.2 \times 10^{3} \mathrm{M}^{-1}\right)$ and a corresponding 35 -fold reduction in affinity for D-Ala-D-Ala $\left(K_{\mathrm{a}}=4.8 \times 10^{3} \mathrm{M}^{-1}\right)$ providing a molecule with balanced, dual binding characteristics. Beautifully, 5 exhibited antimicrobial activity against a VanA resistant organism that remodels its D-Ala-D-Ala peptidoglycan cell wall precursor to D-Ala-D-Lac upon glycopeptide challenge displaying a potency that reflects these binding characteristics.

\section{Supplementary Material}

Refer to Web version on PubMed Central for supplementary material.

\section{Acknowledgements}

We gratefully acknowledge the financial support of the National Institutes of Health (CA 41101) and the Skaggs Institute for Chemical Biology. We wish to thank Drs. M. Lall, D. Horne, J. J. McAtee, O. Rogel, and C. C. McComas for initiating and contributing to studies on the preparation of the modified $\mathrm{CD}$ and $\mathrm{ABCD}$ ring systems and Professor Julius Rebek for his discussions, interest, and encouragement throughout the work. BMC is a Skaggs Fellow and recipient of Bristol-Myers Squibb (2004-2005) and Fletcher Jones Foundation fellowships (2003-2004).

\section{References}

1. Reviews: (a) Kahne D, Leimkuhler C, Lu W, Walsh C. Chem Rev 2004;105:425. [PubMed: 15700951] (b) Hubbard BK, Walsh CT. Angew Chem Int Ed 2003;42:730. (c) Nicolaou KC, Boddy CNC, Bräse S, Winssinger N. Angew Chem Int Ed 1999;38:2096. (d) Williams DH, Bardsley B. Angew Chem Int Ed 1999;38:1172. (e) Malabarba A, Nicas TI, Thompson RC. Med Res Rev 1997;17:69. [PubMed: 8979249]Glycopeptide resistance and analogues: (f) Malabarba A, Ciabatti R. Curr Med Chem 2001;8:1759. [PubMed: 11562292] (g) Pootoolal J, Neu J, Wright GD. Annu Rev Pharmacol Toxicol 2002;42:381. [PubMed: 11807177] (h) Van Bambeke FV, Laethem YV, Courvalin P, Tulkens PM. Drugs 2004;64:913. [PubMed: 15101783] (i) Sussmuth RD. ChemBioChem 2002;3:295. [PubMed: 11933229] (j) Gao Y. Nat Prod Rep 2002;19:100. [PubMed: 11902437] (k) Healy VL, Lessard IAD, Roper DI, Knox JR, Walsh CT. Chem Biol 2000;7:R109. [PubMed: 10801476]

2. McComas CC, Crowley BM, Boger DL. J Am Chem Soc 2003;125:9314. [PubMed: 12889959]

3 . Efforts to modify the residue 4 carbonyl by selective reaction of the amide linking residues 4 and 5 within vancomycin aglycon derivatives have not yet been successful in our efforts and we are unaware of any reports of such modifications. Synthetic reviews: (a) Boger DL. Med Res Rev 2001;21:356. [PubMed: 11579438] (b) Lloyd-Williams P, Giralt E. Chem Soc Rev 2001;30:145. (c) Zhang AJ, Burgess K. Angew Chem Int Ed 1999;38:634. (d) Rao AVR, Gurjar MK, Reddy KL, Rao AS. Chem Rev 1995;95:2135. (e) Evans DA, DeVries KM. Drugs Pharm Sci 1994;63:63. 
4. (a) Boger DL, Miyazaki S, Kim SH, Wu JH, Loiseleur O, Castle SL. J Am Chem Soc 1999;121:3226. (b) Boger DL, Miyazaki S, Kim SH, Wu JH, Castle SL, Loiseleur O, Jin Q. J Am Chem Soc 1999;121:10004.

5. (a) Boger DL, Kim SH, Miyazaki S, Strittmatter H, Weng JH, Mori Y, Rogel O, Castle SL, McAtee JJ. J Am Chem Soc 2000;122:7416. (b) Boger DL, Kim SH, Mori Y, Weng JH, Rogel O, Castle SL, McAtee JJ. J Am Chem Soc 2001;123:1862. [PubMed: 11456806]

6. Crowley BM, Mori Y, McComas CC, Tang D, Boger DL. J Am Chem Soc 2004;126:4310. [PubMed: 15053621]

7. (a) Boger DL, Borzilleri RM, Nukui S, Beresis RT. J Org Chem 1997;62:4721. (b) Boger DL, Borzilleri B, Nukui S. J Org Chem 1996;61:3561. (c) Boger DL, Castle SL, Miyazaki S, Wu JH, Beresis RT, Loiseleur O. J Org Chem 1999;64:70. [PubMed: 11674087] (d) Boger DL, Loiseleur O, Castle SL, Beresis RT, Wu JH. Bioorg Med Chem Lett 1997;7:3199. (e) Boger DL, Beresis RT, Loiseleur O, Wu JH, Castle SL. Bioorg Med Chem Lett 1998;8:721. [PubMed: 9871529] (f) Boger DL, Miyazaki S, Loiseleur O, Wu JH, Jin Q. J Am Chem Soc 1998;120:8920.

8. Boger DL, Borzilleri RM, Nukui S. Bioorg Med Chem Lett 1995;5:3091.

9. Evans DA, Watson PS. Tetrahedron Lett 1996;37:3251.

10. (a) Evans DA, Wood MR, Trotter BW, Richardson TI, Barrow JC, Katz JL. Angew Chem Int Ed 1998;37:2700. (b) Evans DA, Dinsmore CJ, Watson PS, Wood MR, Richardson TI, Trotter BW, Katz JL. Angew Chem Int Ed 1998;37:2704.

11. Solladié-Cavallo A, Nsenda T. Tetrahedron Lett 1998;39:2191.

12. Compound 7 is available in 6 steps ( $37 \%$ overall) from methyl gallate using 3 recrystallizations and was scaled to $300 \mathrm{~g}$, ref. 6 .

13. Compound $\mathbf{6}$ is available in 5 steps (55\% overall) from $(R)$-4-hydroxyphenyl-glycine using 2 recrystallizations and was scaled to $60 \mathrm{~g}$, ref. $7 \mathrm{a}$.

14. Benzyl ether deprotection at higher temperatures $\left(25^{\circ} \mathrm{C}\right)$ may lead to competitive aryl bromide reduction although this was observed in appreciable amounts only when excess Raney Ni was employed.

15. Saponification of $\mathbf{1 1}$ was considerably slower than that of $\mathbf{1 0}$ and occasionally required additional $\mathrm{LiOH}$ for complete conversion to $\mathbf{1 2}$ with little effect on the amount of epimer generated in the reaction.

16. Compound $\mathbf{1 3}$ is available in 3 steps ( $45 \%$ overall) from 4-fluoro-3-nitrobenzaldehyde and was scaled to $30 \mathrm{~g}$, ref. 6.

17. Fan CX, Hao XL, Ye YH. Synth Commun 1996;26:1455.Li H, Jiang X, Ye YH, Fan C, Romoff T, Goodman M. Org Lett 1999;1:91. [PubMed: 10822541]

18. Recent efforts have led to improvements in the vancomycin CD ring closure and utilized for the preparation of the analogous intermediates bearing a residue $4 / 5$ thioamide. Its use in the preparation of $\mathbf{5}$ along with additional vancomycin analogues will be disclosed in due time.

19. Use of Raney Ni for N-Cbz removal was also successful, although lower recoveries (84\%) of the product were observed.

20. Both the added $3 \AA \mathrm{MS}$ and $\mathrm{CaCO}_{3}$ result in cleaner conversions to product. It is not yet clear whether the soluble base under these conditions is $\mathrm{CsF}$ or $\mathrm{Cs}_{2} \mathrm{CO}_{3}$ with precipitation of insoluble $\mathrm{CaF}_{2}$.

21. (a) Nicolaou KC, Takayanagi M, Jain NF, Natarajan S, Koumbis AE, Bando T, Ramanjulu JM. Angew Chem Int Ed 1998;37:2717. (b) Nicolaou KC, Natarajan S, Li H, Jain NF, Hughes R, Solomon ME, Ramanjulu JM, Boddy CNC, Takayanagi M. Angew Chem Int Ed 1998;37:2708. (c) Nicolaou KC, Jain NF, Natarajan S, Hughes R, Solomon ME, Li H, Ramanjulu JM, Takayanagi M, Koumbis AE, Bando T. Angew Chem Int Ed 1998;37:2714. (d) Nicolaou KC, Mitchell HJ, Jain NF, Winssinger N, Hughes R, Bando T. Angew Chem Int Ed 1999;38:240. (e) Nicolaou KC, Li H, Boddy CNC, Ramanjulu JM, Yue TY, Natarajan S, Chu XJ, Brase S, Rubsam F. Chem Eur J 1999;5:2584. (f) Nicolaou KC, Boddy CNC, Li H, Koumbis AE, Hughes R, Natarajan S, Jain NF, Ramajulu JM, Brase S, Solomon ME. Chem Eur J 1999;5:2602. (g) Nicolaou KC, Koumbis AE, Takayanagi M, Natarajan S, Jain NF, Bando T, Li H, Hughes R. Chem Eur J 1999;5:2622. (h) Nicolaou KC, Mitchell HJ, Jain NF, Bando T, Hughes R, Winssinger N, Natarajan S, Koumbis AE. Chem Eur J 1999;5:2648.

22. Reduction of the nitro group was sensitive to the choice of solvent in terms of recovery and observance of side products. 
23. Node M, Nishide K, Fuji K, Fujita E. J Org Chem 1980;45:4275.Evans DA, Ellman JA. J Am Chem Soc 1989;111:1063.

24. Nieto M, Perkins HR. Biochem J 1971;124:845. [PubMed: 4331859]Nieto M, Perkins HR. Biochem J 1971;124:773. [PubMed: 5124385]Nieto M, Perkins HR. Biochem J 1971;124:789. [PubMed: 5124386]

25. McAtee JJ, Castle SL, Jin Q, Boger DL. Bioorg Med Chem Lett 2002;12:1319. [PubMed: 11965380] 


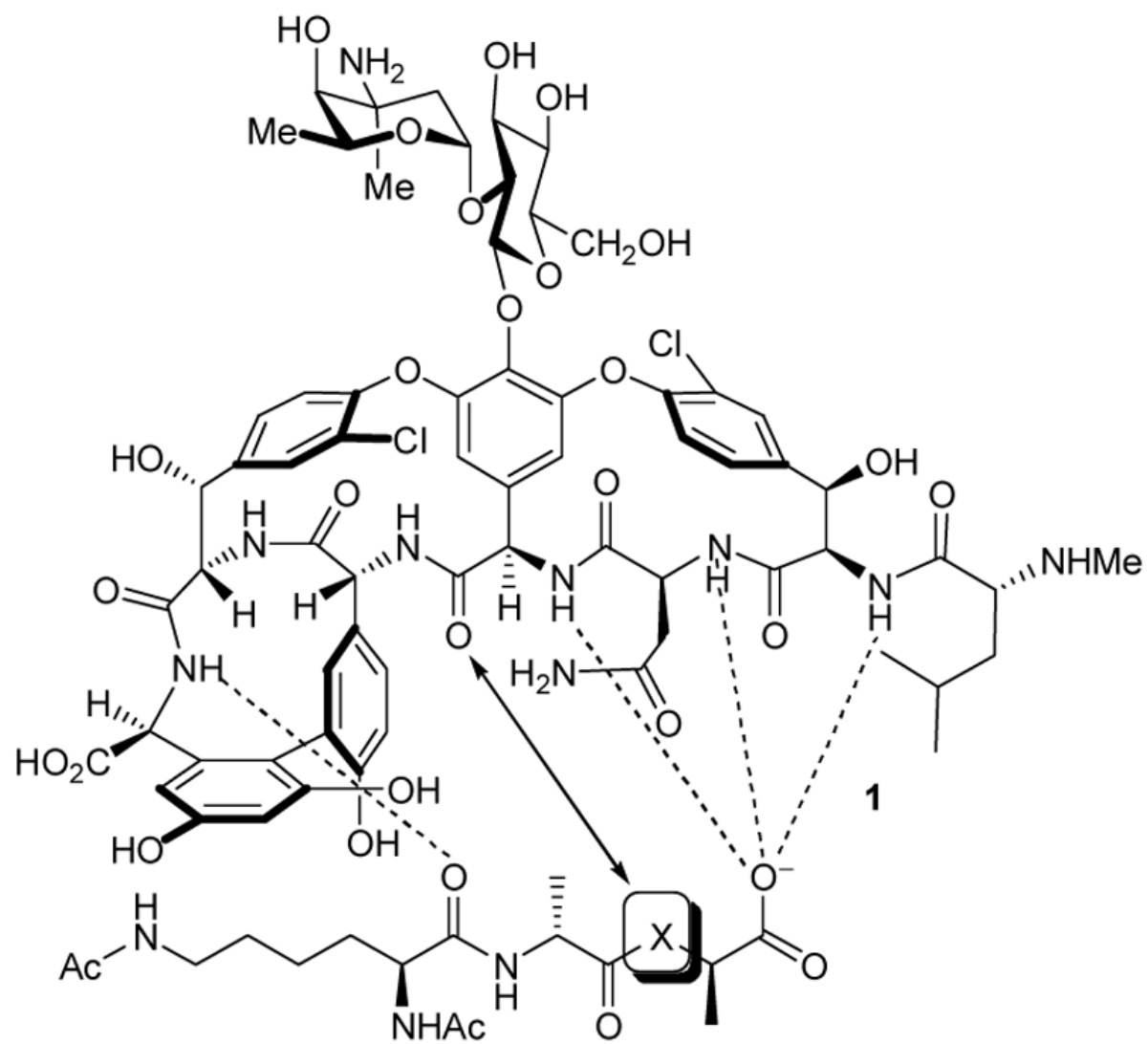

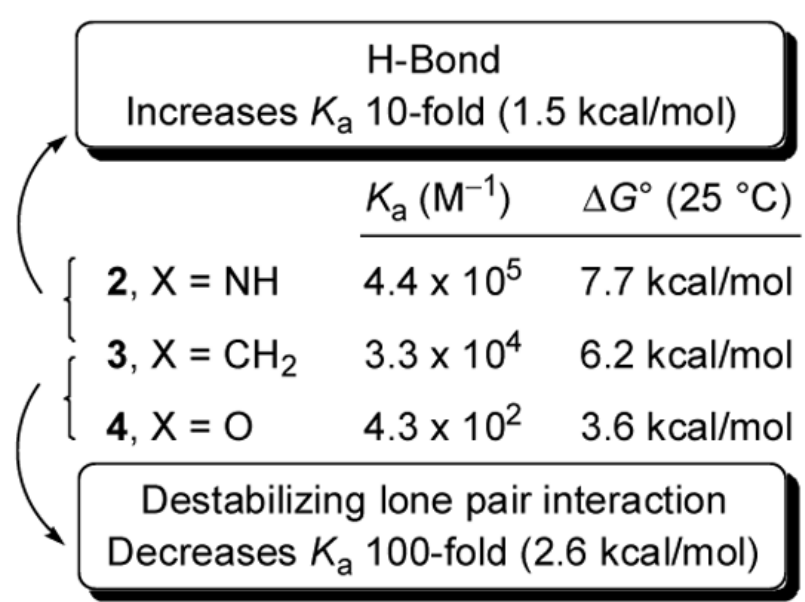

Figure 1.

Binding constants of D-Ala-D-Ala, D-Ala-D-Lac, and a peptide analogue with vancomycin. 


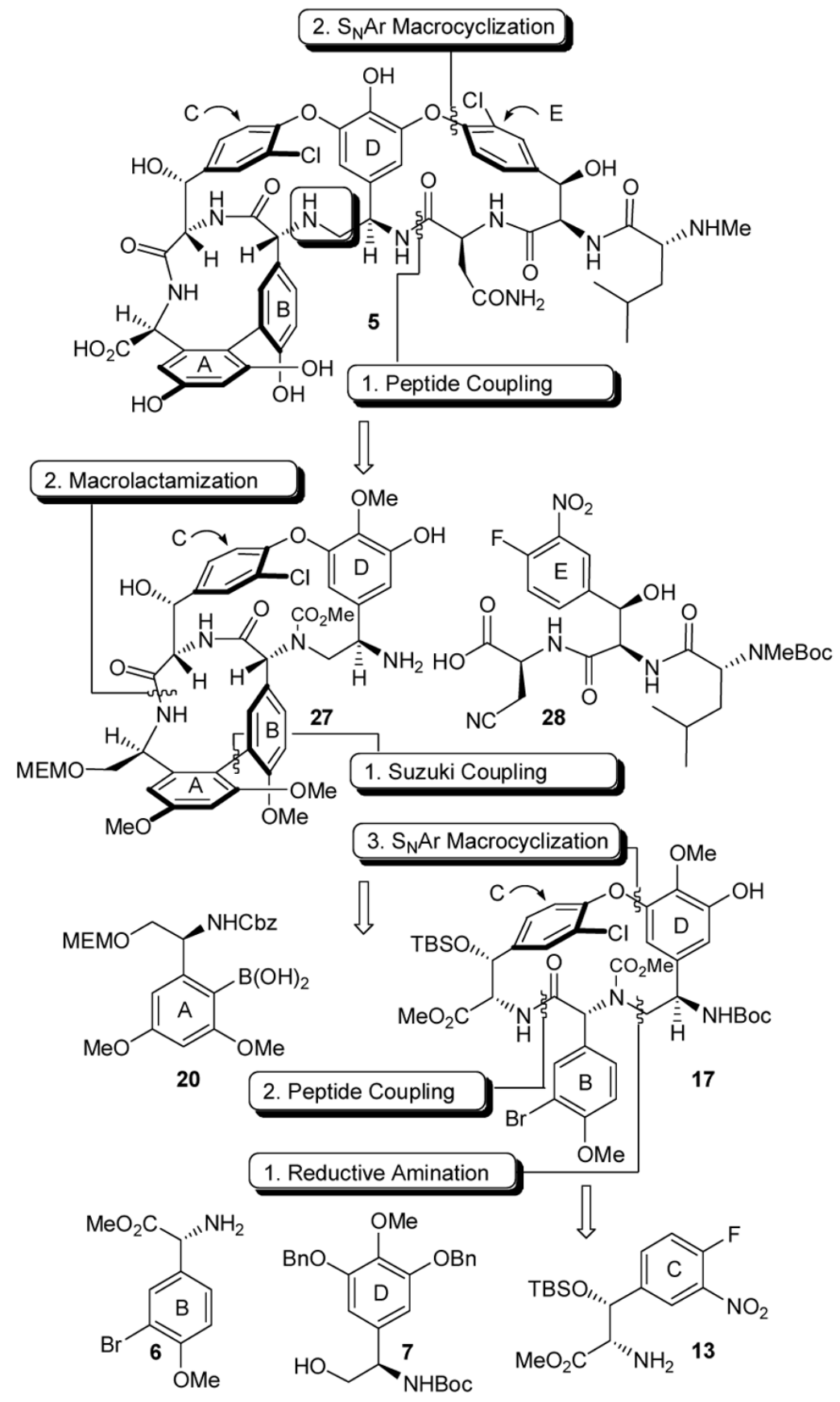

Figure 2.

Plan for $\left[\Psi\left[\mathrm{CH}_{2} \mathrm{NH}\right] \mathrm{Tpg}^{4}\right]$ vancomycin aglycon. 


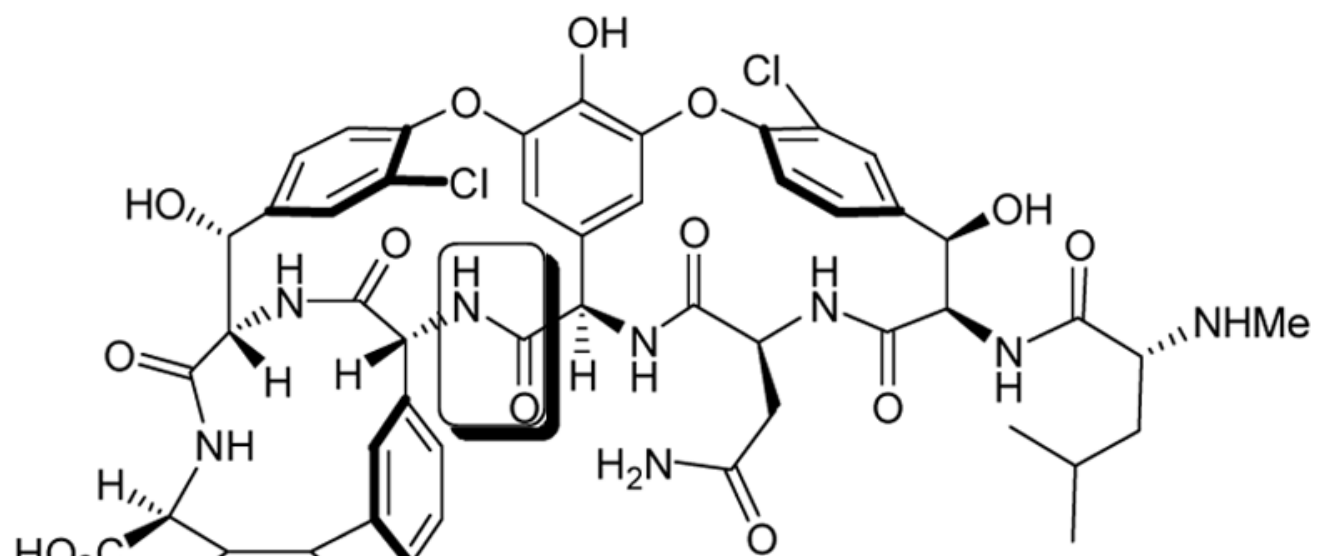

\section{$\mathrm{HO}_{2} \mathrm{C}$}

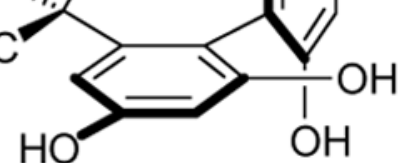

38 , vancomycin aglycon<smiles>CNC(=N)SC</smiles><smiles>C=CC=C</smiles><smiles>C=CC=C</smiles>

39

40<smiles>CCCNC</smiles>

\section{D-Ala-D-Lac \\ $>>$ \\ D-Ala-D-Ala}<smiles>CC=CC</smiles>

5

D-Ala-D-Lac

D-Ala-D-Lac

Figure 3.

Potential modifications. 


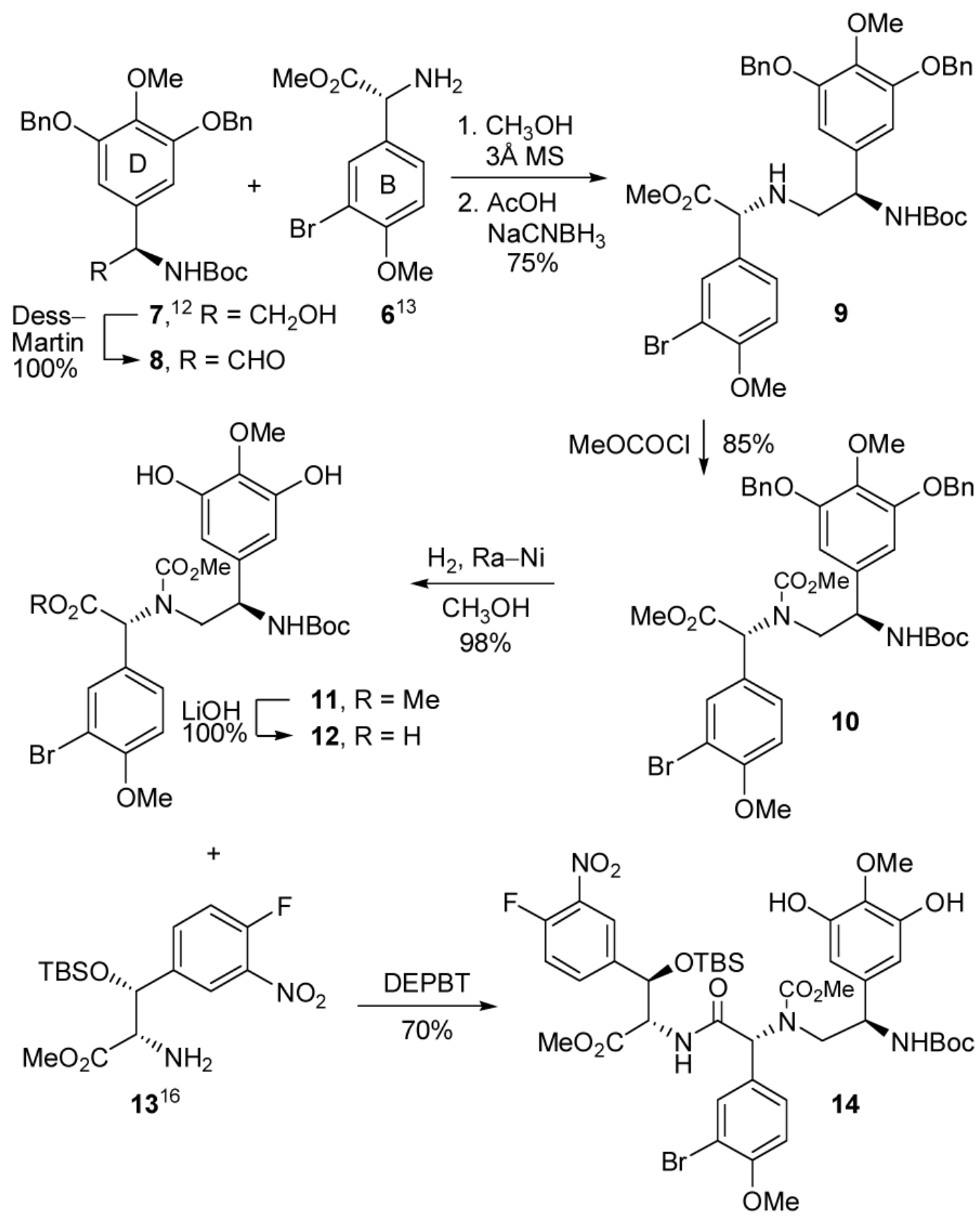

Scheme 1. 


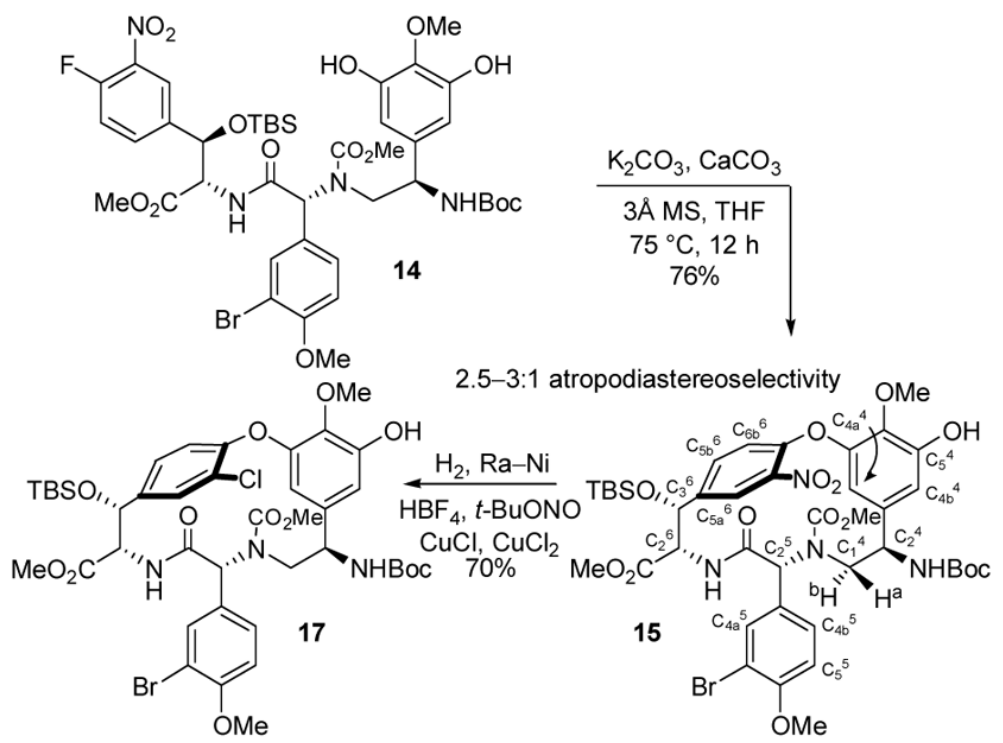

$\mathbf{2 0} \mathbf{0}^{4}, \mathbf{9 0 \%} \mid \mathrm{Pd}_{2}(\mathrm{dba})_{3},(\text { o-tolyl })_{3} \mathrm{P}$

1:1.3 S:R toluene, $\mathrm{CH}_{3} \mathrm{OH}, 1 \mathrm{~N}$ aq $\mathrm{Na}_{2} \mathrm{CO}_{3}, 80^{\circ} \mathrm{C}, 30 \mathrm{~min}$

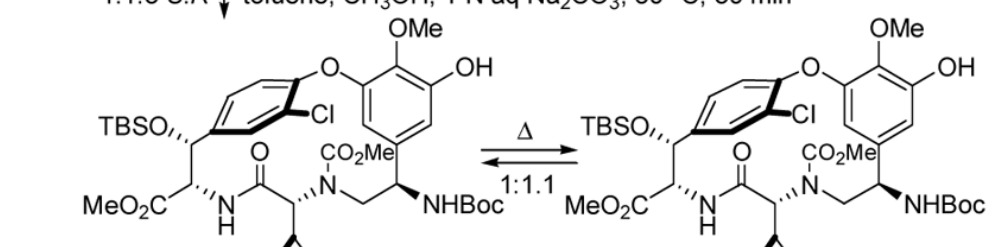

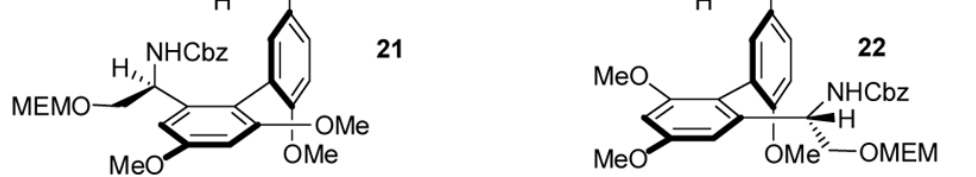

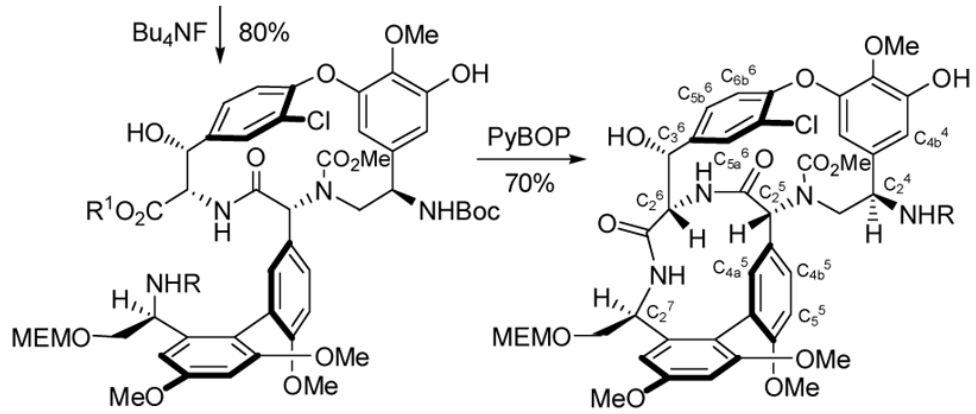

$\mathrm{H}_{2}, \mathrm{Pd} / \mathrm{C}, 95 \% \square \mathbf{2 3}, \mathrm{R}=\mathrm{Cbz}, \mathrm{R}^{1}=\mathrm{Me}$ $\mathrm{LiOH}, 96 \% \longrightarrow 24, \mathrm{R}=\mathrm{H}, \mathrm{R}^{1}=\mathrm{M}$

$\mathrm{HCO}_{2} \mathrm{H}, 84 \% \square 26, \mathrm{R}=\mathrm{BoC}$

$\longrightarrow 25, R=R^{1}=H$

Scheme 2. 


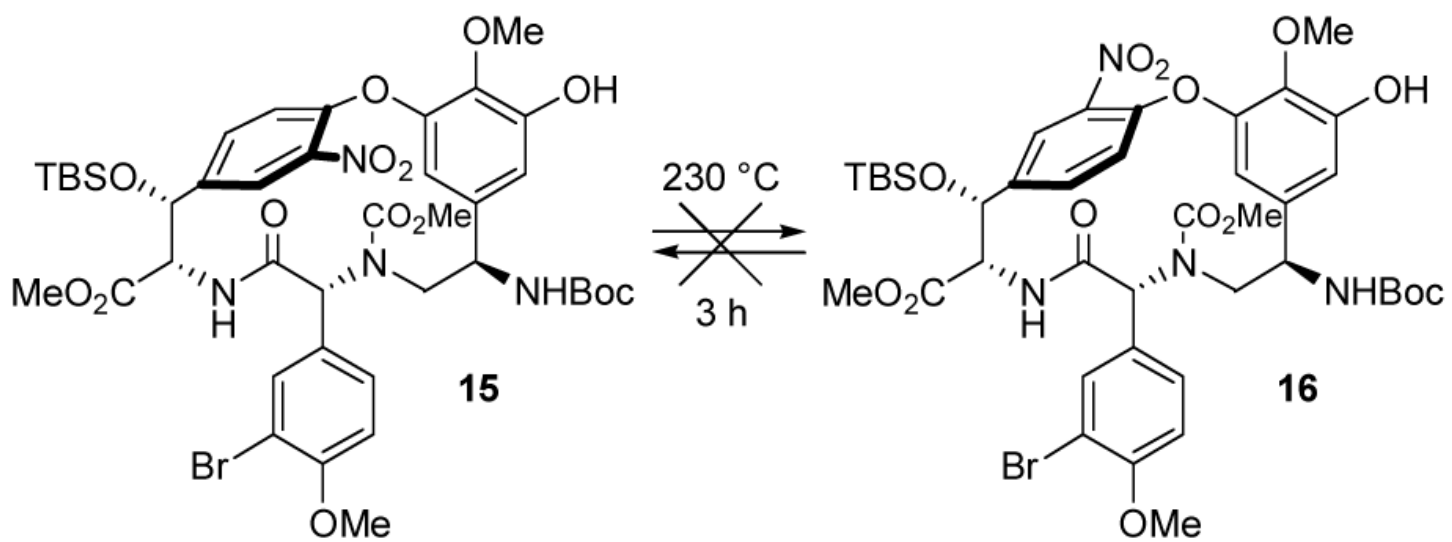

1. $\mathrm{H}_{2}, \mathrm{Ra}-\mathrm{Ni}$
2. $\mathrm{HBF}_{4}, t-\mathrm{BuONO}$;
$\mathrm{CuCl}, \mathrm{CuCl}_{2}$

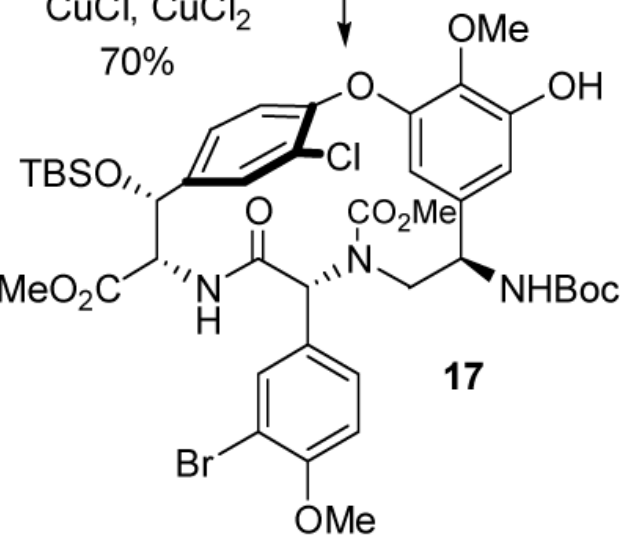

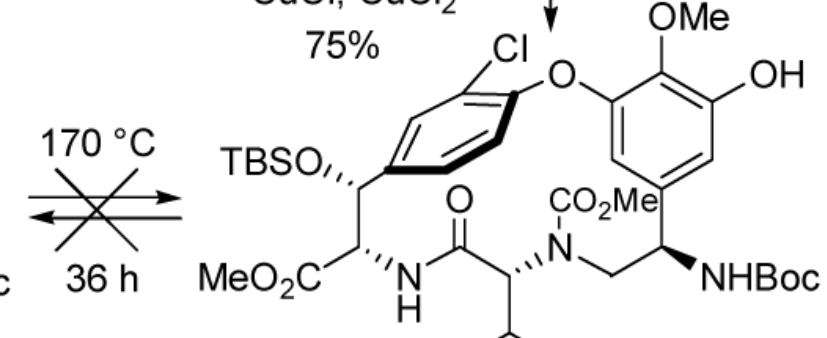

1. $\mathrm{H}_{2}, \mathrm{Ra}-\mathrm{Ni}$

2. $\mathrm{HBF}_{4}, t$-BuONO; $\mathrm{CuCl}, \mathrm{CuCl}_{2}$ $75 \%$

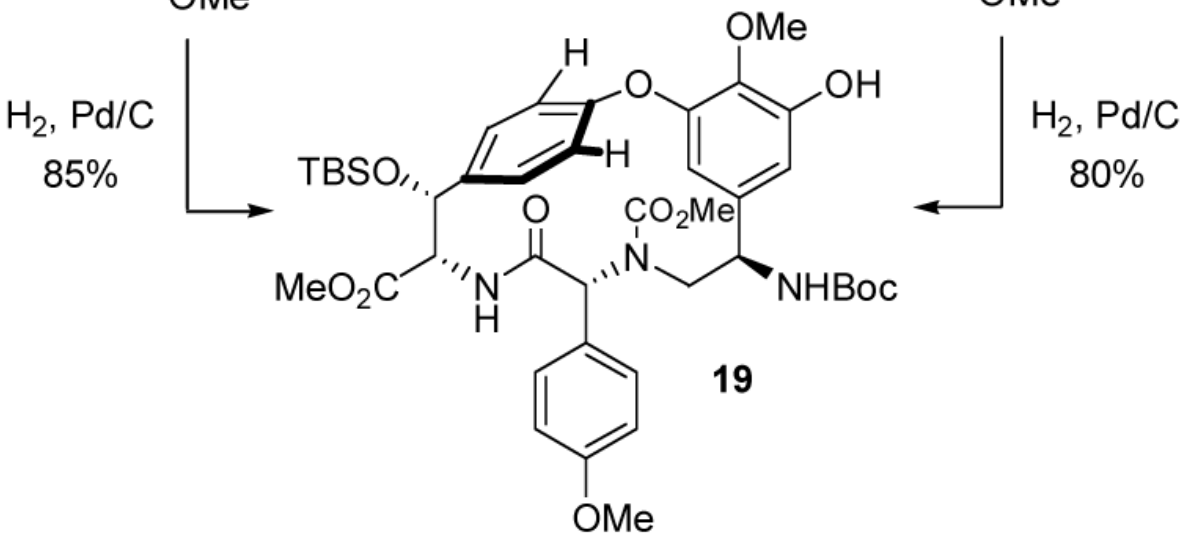

Scheme 3. 

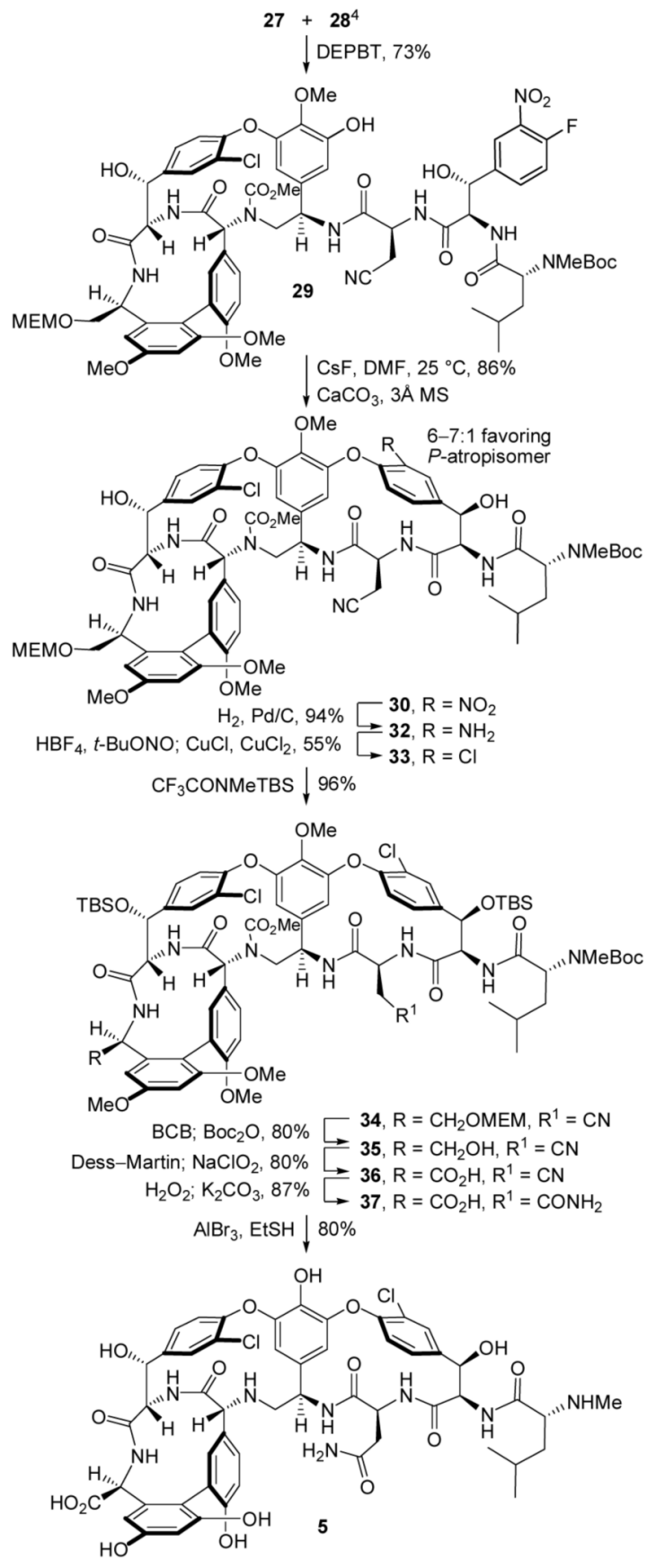

Scheme 4. 
Table 1

Binding and Antimicrobial Properties

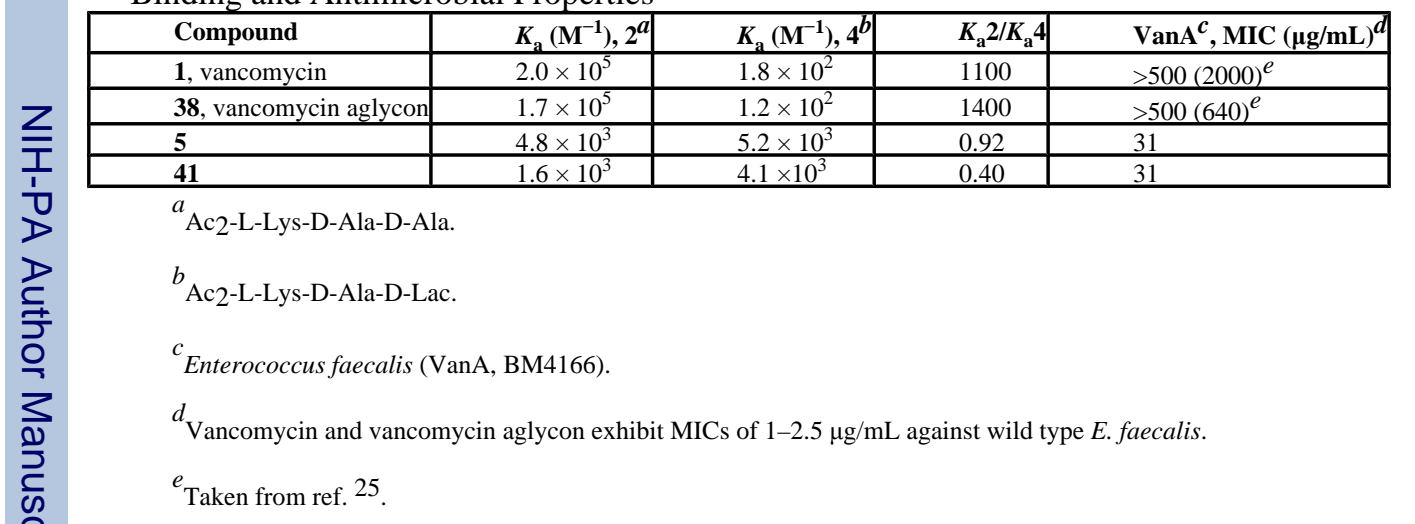

